\title{
Anatomical characterisation of wood decay pattern in Azadirachta indica A. Juss. by the white-rot fungi Irpex lacteus Fr. (Fr.) and Phanerochaete chrysosporium Burds.
}

Rina Dhirajlal Koyani \& Kishore Shankarsinh Rajput

Department of Botany, Faculty of Science, The Maharaja Sayajirao University of Baroda, Vadodara-390 002, India

Correspondence

R.D. Koyani

E-mail: ks.rajput15@yahoo.com

Telf: +91265 2791891

Received: 23 January 2015

Accepted: 25 May 2015

Published on-line: 8 July 2015

\section{Resumen}

Caracterización anatómica del patrón de degradación de la madera de Azadirachta indica A. Juss. por los hongos de la podedumbre blanca Irpex lacteus y Phanerochaete chrysosporium

En estudios in vitro, la madera de Azadirachta indica, inoculada con Phanerochaete chrysosporium y Irpex lacteus, fue completamente invadida en la primera quincena por ambos hongos. No se observó una pérdida de peso apreciable al final del primer mes pero, a continuación, se aceleró y, tras 120 días, se registró un 28$32 \%$ de pérdida de peso. Ambas cepas mostraron delaminación de las fibras como primer signo de la acción fúngica. Sucesivamente, se distinguieron orificios en la pared lateral del parénquima, de forma y tamaño irregular, debido a la deslignificación del margen de las punteaduras. Aparecieron perforaciones adicionales en todos los tipos celulares del xilema, excepto en los vasos. En el estado avanzado, se observó un daño amplio del xilema secundario, con los vasos relativamente resistente mientras que las células parenquimáticas radiales fueron el tipo celular más susceptible.

Palabras clave: Neem, Biodegradación de lignina, Degradación selectiva, Degradación de madera.

\begin{abstract}
In vitro studies on Azadirachta indica wood inoculated with Phanerochaete chrysosporium and Irpex lacteus showed that both fungi completely invade woodblocks within the first fortnight. No appreciable weight loss was observed at the end of first month but subsequently it became faster and 28-32 \% weight loss was recorded after 120 days. Both strains showed delamellation of fibres as the first sign of fungal action. Successively, lateral wall pits of parenchyma became distinct and irregular in shape and size due to delignification from pit margin. Additional boreholes occur on all the cell types of xylem except vessels. At the advanced stage, extensive damage was observed in the secondary xylem, in which vessels were relatively resistant while rays were the most susceptible to cell types.
\end{abstract}

Key words: Neem, Indian lilac, Lignin biodegradation, Selective delignification, Wood decay. 


\section{Introduction}

Azadirachta indica A. Juss., popularly known as Indian lilac or neem, is one of the important trees in traditional Indian medicine system for its multiple applications in various diseases including physical ailments such as heart diseases, disorders of blood, nervous system, and in diabetes (Shravan et al. 2011). It is also used as bio-pesticides and antifungal agent, and in wounds healing, burns, in headache or as tooth brush (Maragathavalli et al. 2012). Looking to all these medicinal properties and its insecticidal and antifungal properties of different parts of plant, it is a notion that $A$. indica wood would also have same properties and therefore it is used as door and window frames. However, there is no information on the Azadirachta wood attacked by frequently occurring fungal strains. In present investigation in vitro decay test was carried out for histological characterisation of wood decayed in response to fungal attack. Two white-rot basidiomycetes Irpex lacteus Fr. (Fr.) and Phanerochaete chrysosporium Burds. occur frequently on decaying wood in forests, in timber yards and on the wood logs lying in saw mills. Therefore, both the white rot fungi are utilised to enumerate the structural alterations induced in the wood cell walls.

The strength of wood material of any timber trees against microbial degradation, wood borers, or beetles is determined by natural durability of the tree and phenolic compounds stored in wood tissue. Durability of the wood is largely determined by the several factors like genetic resistance of the species, its growth rate, age of the tree and local climate to which it is exposed (Suprapti 2010). Wood extractives deposited in the wood cell walls and on the portion of the wood bole i.e. heartwood/sapwood also important aspect of wood resistance (Suprapti 2010). On the basis of cell wall degradation, three different types (viz. white-rot, soft-rot and brown-rot) of wood rot are recognised in the literature. Among them, fungi causing white rot decay have a very high potential of lignin degradation and they are very well adapted to degrade complex structure of angiosperm wood (Schwarze \& Fink 1998).

In contrast, I. lacteus and P. chrysosporium are well known in the literature for the production of ligninolytic enzymes such as laccase and different lignin peroxidases (Agosin et al. 1990; Glenn \& Gold 1983; Maximo \& Costa-Ferreira 2004;
Baborová et al. 2006; Gassara et al. 2010; Koyani et al. 2013). However, there is no information on the pattern of wood decay caused by both the fungal strains. Therefore, present study attempts to investigate the extent of cell wall damage caused by I. lacteus and P. chrysosporium within known period by in vitro study on sapwood portion of $A$. indica wood.

\section{Material and Methods}

\section{Source of fungi}

P. chrysosporium and I. lacteus were exploited in the present study to characterize the pattern of wood decay. Naturally infected wood samples were excised by using chisel and hammer and packed immediately in sterile polyethylene bags. After arriving to laboratory, small pieces of suitably trimmed wood blocks were surface sterilized by $0.1 \% \mathrm{HgCl}_{2}$ for $40-45$ seconds with intermediate washing by sterile distilled water followed by a treatment of $70 \%$ ethanol for few seconds. Thereafter, these samples were inoculated on 2.5 \% Malt Extract Agar (MEA) media. Pure culture was established by serial transfer of the fungus and sent for molecular identification to Chromous Biotech Pvt. Ltd., Bengaluru.

\section{Wood decay test}

Cubic wood blocks from sound sapwood portion of $A$. indica, measuring $2 \times 2 \times 2 \mathrm{~cm}$ was prepared from the stem disc free from knots. Some of the wood blocks were marked to study the weight loss, for which these marked wood blocks were weighed prior to- and after incubation with fungal cultures. Prior to incubation, wood blocks were rewetted in water for $24 \mathrm{hrs}$ to obtain optimum moisture level to facilitate fungal invasion. These wood blocks were autoclaved at $120{ }^{\circ} \mathrm{C}$; subsequently surface sterilised with $70 \%$ ethanol after cooling at room temperature and kept in autoclaved Petri dish containing Malt Extract Agar. Each petri plates were inoculated with 15-day-old pure culture of $P$. chrysosporium and I. lacteus. Each Petri dish containing three blocks was incubated for $30,60,90$ and 120 days at $27 \pm 1{ }^{\circ} \mathrm{C}$ and $70 \%$ relative humidity. Three woodblocks without fungal inoculum were maintained as control. For each incubation period nine treated and three control wood blocks were removed and cleaned to takeout superficial mycelia. Unmarked wood 
blocks were fixed in FAA (Berlyn \& Miksche 1976) for histological study while marked wood blocks were oven dried and percent weight loss was determined as: (weight of oven dried wood after fungal incubation/weight of oven dried original wood block) X 100. After $24 \mathrm{hrs}$ of fixation, these blocks were transferred to $70 \%$ ethanol for further processing and storage. This experiment was performed in triplicates for every incubation period.

\section{Sample processing}

Suitably trimmed samples were dehydrated with Tertiary Butyl Alcohol (TBA) and processed by routine method of paraffin embedding (Berlyn \& Miksche 1976). Transverse, radial and longitudinal sections of $12-15 \mu \mathrm{m}$ thick were cut on Leica Rotary Microtome. Some of the samples were also sectioned directly on sliding microtome and stained with Safranin-Astra blue combination (Srebotnik \& Messner 1994). After dehydration in ethanol-xylene series, the sections were mounted in Dibutyl Phthalate Xylene (DPX). Important results were micro-photographed with a Leica DM 2000 trinocular research microscope attached with Cannon DC 150 digital camera.

\section{Results}

\section{Structure of wood}

Secondary xylem of $A$. indica was diffuse porous with indistinct growth rings. However, annual increment of the secondary xylem may be determined by the presence of tangential bands of axial parenchyma. It was composed of vessels, fibres, axial and ray parenchyma cells. Vessels were mostly solitary but radial multiples of 2-6 vessels were also seen frequently. Xylem rays were unimultiseriate, compound and heterocellular. Vessel elements possess simple perforation plate on transverse end walls and possess alternate bordered pits. Vessel elements were measured about 226-287 $\mu \mathrm{m}$ and $128-179 \mu \mathrm{m}$ in length and width respectively. Xylem fibres were 1192-1368 $\mu \mathrm{m}$ in length. Axial and ray parenchyma were possessed oval to circular simple pits.

\section{Weight loss}

Average percent weight loss of decayed wood blocks for both fungal strains are shown in table
1. However, negligible weight loss (0.68-1.32\%) of control wood samples was observed after 120 days, and that might have been associated with the preparation procedure. Fungal mycelia began to ramify on the wood surface after one week of incubation. Woodblocks were fully covered with mycelial mat after 12-15 days of inoculation. At the initial stage (i.e. after 30 days) of fungal inoculation, no appreciable weight loss of test blocks was observed though mycelia of both the strains completely ramified over the blocks and partially invaded all the cell types. Weight loss by both strains became rapid after 30 days and was found more in samples inoculated with $P$. chrysosporium (Table 1). Analysis of percent weight loss indicates that at the end of 120 days I. lacteus causes relatively least percent weight loss $(23.37 \%)$ as compared to $P$. chrysosporium (29.08\%).

\begin{tabular}{lccc} 
& \multicolumn{3}{c}{$\%$ Weight loss } \\
\cline { 2 - 4 } Decay fungi & $\mathbf{6 0}$ days & $\mathbf{9 0}$ days & $\mathbf{1 2 0}$ days \\
\hline Irpex lacteus & $7.63 \pm 2.29$ & $16.09 \pm 4.23$ & $23.37 \pm 5.48$ \\
\hline $\begin{array}{l}\text { Phanerochaete } \\
\text { chrysosporium }\end{array}$ & $11.18 \pm 1.87$ & $19.97 \pm 5.73$ & $29.08 \pm 4.94$ \\
\hline
\end{tabular}

Tabla 1. Porcentaje de pérdida de peso de madera de Azadirachta indica durante cada periodo de incubación.

Table 1: Percent weight loss of Azadirachta indica wood during each incubation period.

\section{Degradation of wood}

After 30 days of inoculation, mycelia of both the strains completely masked the wood block and began to invade xylem cells. At the initial stage, mycelia invasion takes place through the vessel lumen (Figs. 1a, b), from which it traversed into the neighboring rays and vessels associated axial parenchyma cells (Fig. 1c). Gradually they extended in all direction including fibres and adjacent axial parenchyma cells (Fig. 1d). Vessels and axial parenchyma served as the main path for vertical movement and invasion of wood cells (Fig.1d) while rays facilitated radial dispersal of mycelia. At this stage no visual damage was observed in the cell walls of the xylem derivatives. Hyphal movement takes place through the pits present on their walls. Due to secretion of ligninolytic enzymes, pits become large in size and irregular in shape. Presence of fungal mycelia in all the cell types of xylem adjacent to vessel elements was a common feature in all the samples studied. 

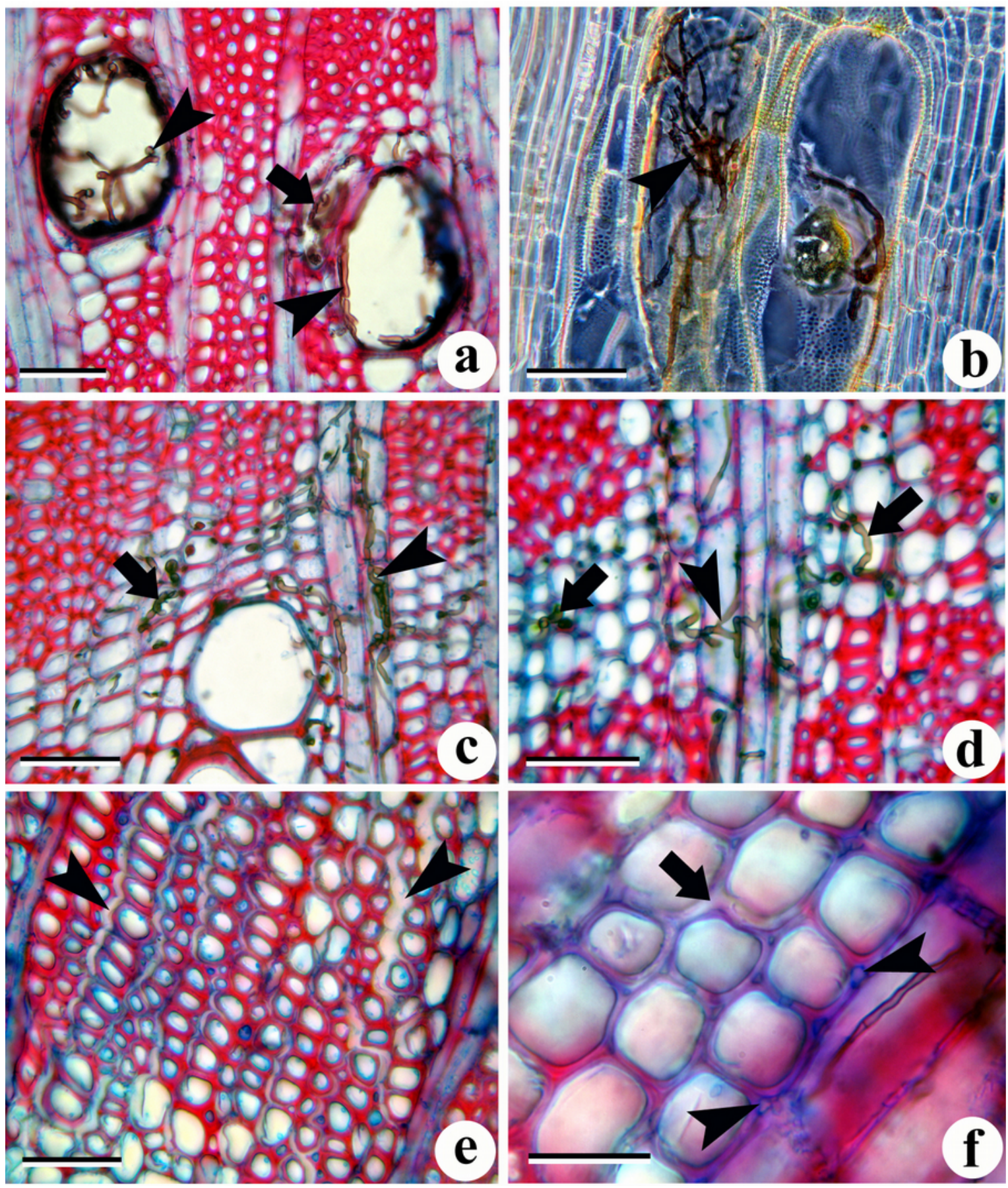

Figura 1. Vistas transversales (a, c-f) y longitudinal (b) del xilema de Azadirachta indica inoculado con Phanerochaete chrysosporium e Irpex lacteus. a: El micelio de I. lacteus invade el xilema a través del lumen del vaso (punta de flecha) y penetra en la célula adyacente en las primeras etapas. La flecha indica el micelio en la célula parenquimática asociada al vaso; b: Micelio de P. chrysosporium (punta de flecha) en el lumen del vaso; c: El micelio pasa de los vasos a su parénquima asociado (flecha) y células radiales (punta de flecha); d: Elementos del xilema invadidos por P. chrysosporium que no muestran daños visibles durante el primer mes. Se señala las hifas en las células parenquimáticas radiales (punta de flecha) y axiales (flecha); e: Fibras del xilema mostrando separación entre las paredes celulares a lo largo de la lámina media (punta de flecha); f: Disolución de la lámina media en las esquinas de las células del parénquima axial (punta de flecha). Nótese la separación del parénquima axial indicativo de deslignificación selectiva (flecha). Escala a-d $=150 \mu \mathrm{m} ; \mathrm{e}=100 \mu \mathrm{m} ; \mathrm{f}=75 \mu \mathrm{m}$.

Figure 1: Transverse (a, c-f) and longitudinal (b) views of Azadirachta indica xylem inoculated with Phanerochaete chrysosporium and Irpex lacteus. a: I. lacteus mycelia invade xylem through vessel lumen (arrowheads) and penetrate in adjacent cell during early stages. Arrow indicates mycelia in vessel associated parenchyma cell; b: P. chrysosporium (arrowhead) forms mycelial mat within the vessel lumen; c: Fungal mycelia traverse from vessels into vessel associated parenchyma (arrow) and ray cells (arrowhead); d: Xylem elements invaded with P. chrysosporium show no visual damage at the end of first month. Note the fungal hyphae in ray (arrowhead) and axial parenchyma cells (arrows); e: Xylem fibres showing separation of cell walls along the middle lamella (arrowheads); f: Dissolution of middle lamella at the cell corners of axial parenchyma (arrowheads). Note the separation of axial parenchyma (arrow) indicating selective delignification. Scale bar a-d $=150 \mu \mathrm{m} ; \mathrm{e}=100 \mu \mathrm{m} ; \mathrm{f}=75 \mu \mathrm{m}$. 
After 60 days, both the fungus attacked all cell types of secondary xylem. At this stage delamellation of xylem fibres, axial and ray parenchyma was much pronounced (Figs. 1e, f, 2a). Fibres and ray cells became separated along with the middle lamella due to dissolution of middle lamella in response to secretion of extra cellular ligninolytic enzymes (Figs. 1e, f). Axial parenchyma also showed similar behavior (Fig. 2b). As a result, the secondary wall adjacent to the middle lamellae stained blue with Astra blue instead of red by safranin. This feature was initially observed in the xylem cells adjacent to the rays (Fig. 1e, f), followed by fibres adjacent to the axial parenchyma and vessel elements. At this stage, separation of the cell walls was the only characteristic feature of wood damage in axial system. The middle lamellae that were stained blue began to lose the integrity and individual cells became separated from each other. As the degradation progressed further, complete separation of fibres was more common (Fig. 1e). Except defibration, no much visual damage was observed in the axial elements while the radial system showed considerable alterations in the cell walls. At this stage, pits on the ray and axial parenchyma cells became more pronounced and became larger in size. Ray cells also showed thinning of the cell walls and formation of additional bore holes on the lateral walls (Fig. 2b). Formation of boreholes on the lateral walls of the ray cells were more common and observed frequently in all the samples treated with both the strains. However, the effect was more pronounced in wood samples inoculated with $P$. chrysosoprium.

Deterioration of cell components became more evident after 90 days of incubation. At this stage, vessels also start separating from each other (Fig. 2c). Except separation, no much damage was observed in the vessels wall. Pits on the lateral walls of the fibres became larger in size (Fig. 2d), irregular in shape and showed blue staining at the pit margin with Astra blue due to removal of lignin. Beside lateral wall pits, mycelial movement also occurs by transverse boring through the wall (Figs. 2e-f). At the end of 120 days, secondary xylem inoculated with both strains showed extensive damage to cell walls. Compared to other cell types, axial and ray parenchyma were severely affected and showed several irregularly arranged oval to oblong boreholes (Fig 3a, b).
These boreholes were 5-7 $\mu \mathrm{m}$ in tangential diameter but most of the times 2-3 cavities fuse together to form a relatively larger one. Though, vessels were not much affected with fungal invasion but vessels arranged in the form of radial or tangential multiples showed separation due to the dissolution of middle lamella (Fig. 3c). At this stage, fibres showed distinct "U" shape erosion troughs on the wall facing cell lumen due to mycelial action. Troughs became deeper and at some portion it even reached to the middle lamella (Fig. 3d).

\section{Discussion}

Fungi are indispensible group of saprophytes in the forest ecosystem and play pivotal role in recycling of carbon stored in the form of complex organic matter (Fazio et al. 2010; Sanghvi et al. 2013). In contrast, they also destruct wood, which causes large economic losses by degrading cell wall components of wood cells. Chemical and micro-morphological pattern of wood degradation remains characteristic for each group of fungi, which are classified into white-rot, soft-rot and brown rot fungi (Liese 1970; Eaton \& Hale 1993; Blanchette 1991, 2000; Boddy \& Watkinson 1995; Schwarze 2007; Koyani et al. 2010). In the present study, I. lacteus and P. chrysosporium are used for in vitro decay test. Both fungi initially showed selective delignification of white-rot pattern of wood degradation but later on simultaneous decay pattern becomes dominant.

Even though, both the strains completely ramify the wood blocks within short period of inoculation and invade all the cell types of xylem, no appreciable weight loss occurs at the end of first month. Presence of several low molecular weight compounds in wood cells might be acting as a source of carbon during this stage which consequently resulting in no weight loss. The fungi consume these compounds in the initial stage of attack without damaging cell wall polymers (Fengel \& Wegener 1984; Worrall et al. 1997). According to Worrall et al. (1997) fungi that cause wood decay less than $2 \%$ during decay test may not be true decomposers and therefore, they may be mycoparasites or scavengers. In the present study, weight loss becomes rapid after one month and about $23.37 \%$ (I. lacteus) and $29.08 \%$ (P. chrysosporium) weight loss is observed after 120 days of incubation. Increase in the per cent 

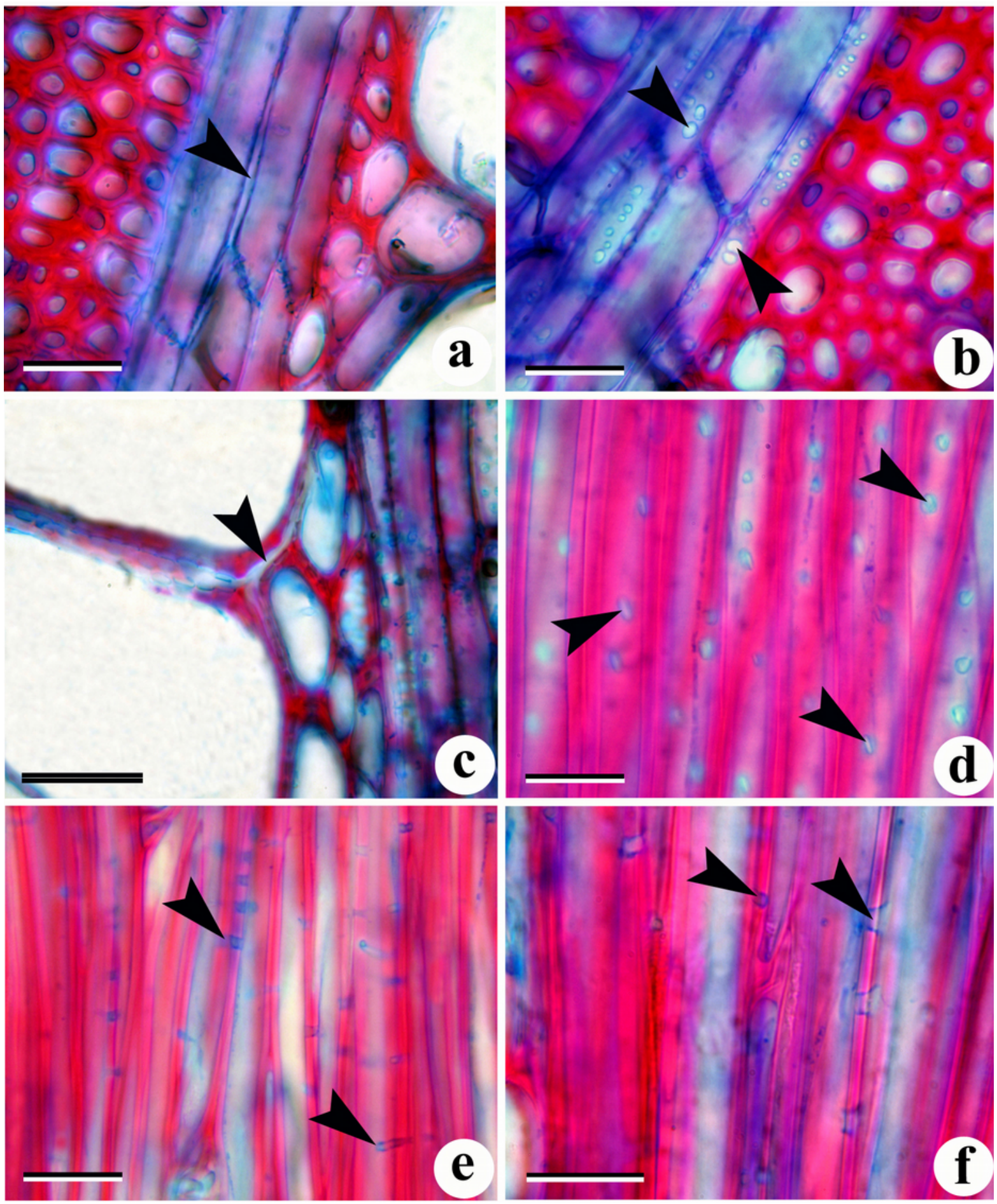

Figura 2: Vistas transversales (a-c) y longitudinales (d-f) del xilema de Azadirachta indica inoculado con Irpex lacteus (a, b, d) y Phanerochaete chrysosporium (c, e, f). a: Separación de las células radiales (punta de flecha) por disolución de la lámina media; b: Pared de célula radial mostrando orificios de erosión grandes (punta de flecha); c: Disolución de la lámina media y separación de los elementos de la pared de los vasos (punta de flecha); d: Erosión del margen de la punteadura mostrando color azul debido a la eliminación de la lignina de las fibras (punta de flecha); e: Perforación (punta de flecha) de las fibras de la pared mostrando el rastro del movimiento de las hifas. Las distintas perforaciones aparecen como túneles; f: Detalle aumentado de fibras de la pared mostrando las perforaciones. Escala $75 \mu \mathrm{m}$.

Figure 2: Transverse (a-c) and longitudinal (d-f) views of Azadirachta indica xylem inoculated with Irpex lacteus (a, b, d) and Phanerochaete chrysosporium (c, e, f). a: Separation of ray cells (arrowhead) by dissolution of middle lamella; b: Ray cell wall showing large erosion holes on the wall (arrowheads); c: Dissolution of middle lamella and separation of vessel elements (arrowhead); d: Erosion of pit margin showing blue color due to the removal of lignin from the fibre walls (arrowheads); e: Boreholes (arrowheads) on the fibre walls showing path of mycelial movement. Note the distinct boreholes appearing like tunnels; f: Enlarged view of fibre walls showing boreholes (arrowheads). Scale bar $=75 \mu \mathrm{m}$. 

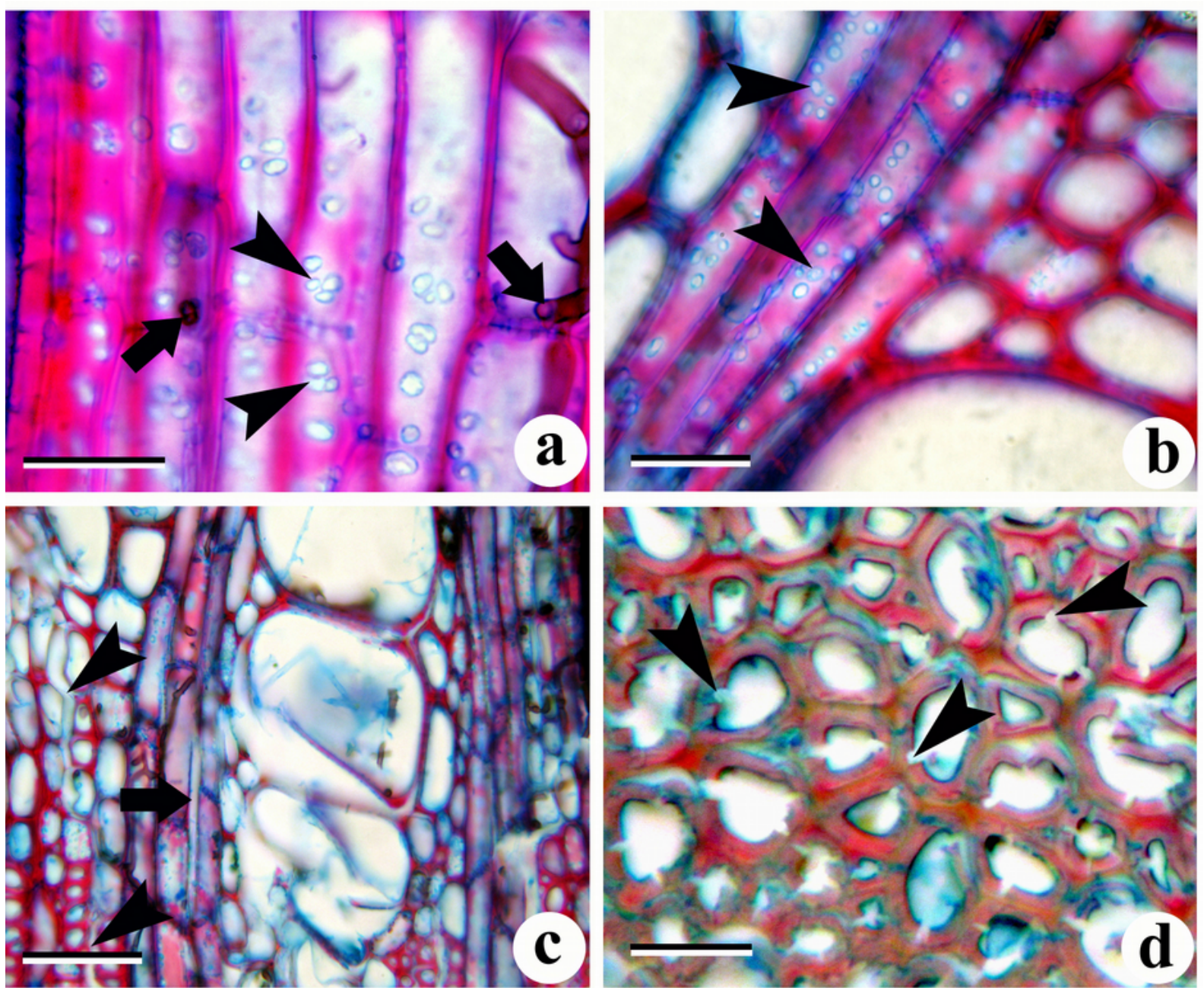

Figura 3:Vistas longitudinal (a) y transversales (b-d)) del xilema de Azadirachta indica inoculado con Irpex lacteus (a, c) y Phanerochaete chrysosporium (b, d); a: Células parenquimáticas axiales muy dañadas mostrando diversas perforaciones (cabeza de flecha) e hifas (flecha); b: Desarrollo de numerosas perforaciones en las células parenquimáticas axilaes en el estado avanzado de putrefacción debido a la accion del micelio (cabeza de flecha); c: Tras tres meses de incubación, el xilema muestra separación de las fibras (cabeza de flecha), células parenquimáticas radiales deformadas (flecha) y vasos; d: Madera severamente degradada mostrando depresiones por erosión en forma de U en las fibras de la pared opuestas al lumen (cabeza de flecha). Escala a, b, $d=75 \mu \mathrm{m} ; \mathrm{c}=150 \mu \mathrm{m}$.

Figure 3: Longitudinal (a) and transverse (b-d) view of Azadirachta indica xylem inoculated with Irpex lacteus (a, c) and Phanerochaete chrysosporium (b, d); a: Severely damaged axial parenchyma cells showing several boreholes (arrowheads) and fungal hyphae(arrow); b: At the advanced stage of decay ray cells develop several boreholes due to mycelial action (arrowheads); c: After three months of fungal incubation xylem show separation of fibres (arrowheads), ray cells (arrow) and deformed vessels; d: Severely degraded wood showing "U" shaped erosion troughs on the fibre wall facing fibre lumen (arrowheads). Scale bar a, b, d= $75 \mu \mathrm{m} ; \mathrm{c}=150 \mu \mathrm{m}$.

weight loss indicates greater removal of cell wall polysaccharides and lignin. Anatomically, both species used in the present study responded similarly but the per cent weight loss is relatively more by $P$. chrysosporium. According to Adaskaveg et al. (1995) the rate and extent of polysaccharides and lignin removal differs among different white-rot fungi i.e. some fungi like Chrysosporium asperatum J.W. Carmich. remove cell wall component simultaneously while others such as $P$. chrysosporium remove lignin preferentially (Adaskaveg et al. 1995; Schwarze 2007;
Koyani et al. 2010; Sanghvi et al. 2013). In the present study, initially both fungal species showed preferential delignification but in the later stage they show simultaneous degradation of cell wall components.

Fungal mycelia enter through vessels and further invasion in other cell types is facilitated by axial and ray parenchyma cells (Rayner \& Boddy 1988; Schwarze et al. 2004, 2008; Koyani et al. 2010; Sanghvi et al. 2013). On the basis of removal of cell wall constituents, two types of white-rot degradation are recognised: i) preferen- 
tial or selective delignification and ii) simultaneous (Worrall et al. 1997; Blanchette 2000; Schwarze 2007; Koyani et al. 2010; Sanghvi et al. 2013). Simultaneous white-rot degrade all the structural components including lignin uniformly and form erosion pit on the cell wall at contact side (Worrall et al. 1997). In contrast, preferential degradation removes hemicelluloses and lignin preferentially at least in the early stages and most remarkable feature is separation of xylem fibres by dissolution of middle lamella (Worrall et al. 1997). In the present study, I. lacteus and $P$. chrysosporium shows selective delignification by separation of fibres and ray cells after 60 days and vessel elements at an advanced stage of decay. Dissolution of middle lamella and blue staining of pit margin and degraded xylem elements by astra blue instead of red by safranin is reliable indicator of selective delignification (Srebotnik and Messener 1994; Anagnost 1998; Luna et al. 2004).

The effect of fungal action is more pronounced after 90 days of inoculation. Mycelia penetrate horizontally through fibre wall by forming boreholes. However, similar pattern of borehole formation by Fomes fomentarius (L.) Fr. is reported by Schwarze (2007), which shows simultaneous rot. Beside boreholes, formation of erosion troughs in response to decomposition of wall material occurs where the hypha grows (Schwarze 2007). In the present study, no such erosion troughs are observed in the early stage of fungal inoculation but at the end of 120 days development of "U" shaped erosion troughs by both strains are observed on the cell wall facing lumen side. Available literature indicates that same fungal species may show both i.e. selective and simultaneous rot during the course of wood degradation (Blanchette 1984a, b; Koyani et al. 2011; Sanghvi et al. 2013). In the present investigation, at the advanced stage of decay formation of erosion troughs in the fibre walls indicates simultaneous rot pattern of wood decay. Earlier researchers have also reported similar pattern of wood decay in other species (Schwarze 2007; Worall et al 1997; Koyani et al 2011).

In the advance stage, where xylem fibres and axial parenchyma cells are severely affected by fungal action; vessel elements are found relatively unaffected. Available literature indicates that high lignin to carbohydrate ratio and monomeric com- position of lignin is associated with the relative resistance of vessel wall to fungal action (Iiyama \& Pant 1988; Schwarze et al. 2000). Nakano \& Meshitsuka (1978) and Iiyama \& Pant (1988) reported higher content of syringyl monomer in fibres and ray parenchyma, which shows peak uvabsorbance at short wave length (Fergus \& Goring 1970a, b) while fibre tracheid contains high guaiacyl monomer content. If these results are correlated with the present study, it appears that persistence of vessels may be due to higher content of guaiacyl monomer content as reported earlier (Blanchette et al. 1987, 1988; Schwarze et al. 2000). Similar pattern is also observed in our previous study on Ailanthus Desf. and other wood material (Koyani et al. 2010; Koyani 2011).

In conclusion, mycelia of $I$. lacteus and $P$. chrysosporium invade sound wood of $A$. indica through the vessel elements and further invasion is facilitated by axial and ray parenchyma cells. Initially weight loss of woodblocks was slow which might be due to presence of low molecular weight compounds in the wood cells but it became rapid after a month. Both the fungi initially show selective delignification, which is characterized by separation of fibres and even vessels at advanced stage of decay, cell wall thinning, formation of erosion holes on fibre walls, and axial and ray parenchyma cells. Compared to axial and ray parenchyma cells, vessels are more resistance. In the later stage formation of boreholes is similar to simultaneous rot but differs in absence of erosion troughs for initial period but at the end of 120 days, "U" shaped erosion troughs are observed on the fibre wall facing cell lumen indicates that both the strains cause simultaneous pattern of white-rot.

\section{Acknowledgements}

Authors are thankful to Council of Scientific and Industrial Research (CSIR), New Delhi for financial support. Thanks are also due to Prof. J.J. Presa (Editor) and both the anonymous reviewers for their suggestions to improve the manuscript.

\section{References}

Adaskaveg JE, Gilbertson RL \& Dunlap MR. 1995. Effects of incubation time and temperature on in vitro selective delignification of Silver Leaf Oak by Gano- 
derma colossum. Applied and Environmental Microbiology 61: 139-144.

Agosin E, Blanchette RA, Silva H, Lapierre C, Cease KR, Ibach RE, Abad AR \& Mugas P. 1990. Characterization of Palo Podrido, a natural process of delignification in wood. Applied and Environmental Microbiology 56: 65-74.

Baborová P, Moder M, Baldrian P, Cajthamlová K \& Cajthaml T. 2006. Purification of a new manganese peroxidase of the white-rot fungus Irpex lacteus, and degradation of polycyclic aromatic hydrocarbons by the enzyme. Research in Microbiology 157: 248253.

Berlyn GP \& Miksche JP. 1976. Botanical Microtechnique and Cytochemistry. The lowa State University Press, Ames, lowa, pp. 326.

Blanchette RA. 1984a. Screening wood decayed white rot fungi for preferential lignin degradation. Applied \& Environmental Microbiology 48(3): 647-653.

Blanchette RA. 1984b. Selective delignification of eastern hemlock by Ganoderma tsugae. Phytopathology 74(2): 153-160.

Blanchette RA. 1991. Delignification by wood-decay fungi. Annual Review of Phytopathology 29: 381398.

Blanchette RA. 2000. A review of microbial deterioration found in archaeological wood from different environments. International Biodeterioration and Biodegradation 46: 189-204.

Blanchette RA, Obst JR, Hedges JI \& Weliky K. 1988. Resistance of hardwood vessels to degradation by white rot Basidiomycetes. Canadian Journal of Botany 66: 1841-1847.

Blanchette RA, Otjen L \& Carlson MC. 1987. Lignin distribution in cell walls of birch wood decayed by white rot basidiomycetes. Phytopathology 77: 684-690.

Boddy L \& Watkinson SC. 1995. Wood decomposition, higher fungi and their role in nutrient redistribution. Can. J. Bot. 73: S1377-S1383.

Eaton RA \& Hale MDC. 1993. Wood-decay, pests and protection. Chapman \& Hall, London, United Kingdom, pp. 546.

Fazio AT, Papinutti L, Gómez BA, Parera SD, Rodríguez RA, Siracusano G \& Maier MS. 2010. Fungal deterioration of a Jesuit South American polychrome wood sculpture. International Biodeterioration and Biodegradation 64: 694-701.

Fengel D \& Wegener G. 1989. Wood: chemistry, ultrastructure, reactions (2nd Edn). Walter de Gruyter, Berlin, Germany. pp.613.

Fergus BJ \& Goring DAI. 1970a. The location of guaiacyl and syringyl lignins in birch xylem tissue. Holzforschung 24: 113-117.

Fergus BJ \& Goring DAl. 1970b. The distribution of lignin in birch wood determined by ultraviolet microscopy. Holzforschung 24: 118-124.

Gassara F, Satinder K, Brara RD, Tyagi M \& Verma RYS. 2010. Screening of agro-industrial wastes to produce ligninolytic enzymes by Phanerochaete chrysosporium. Biochemical Engineering Journal 49: 388-394.
Glenn JK \& Gold MH. 1983. Decolorization of several polymeric dyes by the lignin-degrading basidiomycete Phanerochaete chrysosporium. Applied and Environmental Microbiology 45: 1741-1747.

liyama K \& Pant R. 1988. The mechanism of the Maule colour reaction. Introduction of methylated syringyl nuclei in softwood lignin. Wood Science and Technology 22: 167-175.

Koyani RD, Sanghvi GV, Bhatt IM \& Rajput KS. 2010. Pattern of delignification in Ailanthus excelsa Roxb, wood by Inonotus hispidus. Mycology 1: 204-211.

Koyani RD, Sanghvi GV, Sharma RK \& Rajput KS. 2013. Contribution of lignin degrading enzymes in decolourisation and degradation of reactive textile dyes. International Biodeterioration and Biodegradation 77:1- 9.

Koyani RD. 2011. Screening of wood rot fungi for bioremediation of xenobiotic compounds. Ph. D. Dissertation, The Maharaja Sayajirao University of Baroda, Vadodara, India.

Liese W. 1970. Ultrastructural aspects of woody tissues disintegration. Annual Review of Phytopathology 8: 231-258.

Luján Luna ML, Murace MA, Keil GD, Otaño ME. 2004. Patterns of decay caused by Pycnoporus sanguineus and Ganoderma lucidum (Aphyllophorales) in poplar wood. IAWA J 25(4): 425-433.

Maragathavalli S, Brindha S, Kaviyarasi NS, Annadurai B \& Gangwar SK. 2012. Antimicrobial activity in leaf extract of neem (Azadirachta indica Linn.). International Journal of Science \& Nature 3: 110-113.

Maximo C \& Costa-Ferreira M. 2004. Decolourisation of reactive textile dyes by Irpex lacteus and lignin modifying enzymes. Process Biochemistry 39: 14751479.

Nakano J \& Meshitsuka G. 1978. Studies on the mechanism of lignin colour reaction. XII. Maule color reaction. Mokuzai Gakkaishi 24: 563-568.

Rayner ADM \& Boddy L. 1988. Fungal Decomposition of Wood: Its Biology and Ecology. - John Wiley, Chichester, UK, pp. 587.

Sanghvi GV, Koyani RD, \& Rajput KS. 2013. Anatomical characterization of teak wood (Tectona grandis L.f.) decayed by fungus Chrysosporium asperatum. Journal of Tropical Forest Science 25(4): 547-553.

Schwarze FMWR \& Fink S. 1998. Host and cell type affect the mode of degradation by Meripilus giganteus. New Phytologists 139: 721-731.

Schwarze FMWR, Baum S \& Fink S. 2000. Resistance of fibre regions in wood of Acer pseudoplatanus degraded by Armillaria mellea. Mycological Research 104: 126-132.

Schwarze FMWR, Mattheck C \& Engels J. 2004. Fungal strategies of wood decay in trees. Springer Verlag, Heidelberg.

Schwarze FMWR, Spycher M \& Fink S. 2008. Superior wood for violins-wood decay fungi as a substitute for cold climate. New Phytolgists 179: 1095-1104.

Schwarze FMWR. 2007. Wood decay under the microscope. Fungal Biology Review 21: 133-170.

Shravan Kumar M \& Nagappan K. 2011. Invivo antidia- 
betic evaluation of Neem leaf extract in alloxan induced rats. Journal of Applied Pharmaceutical Science 7: 100-105.

Srebotnik E \& Messener K. 1994. A simple method that uses differential staining and light microscopy to assess the selectivity of wood delignification by white rot fungi. Applied and Environmental Microbiology
60: $1383-1386$.

Suprapti S. 2010. Decay resistance of 84 Indonesian wood species against fungi. Journal of Tropical Forest Science 22: 81-87

Worrall JJ, Anagnost SE \& Zabel RA. 1997. Comparison of wood decay among diverse lignicolus fungi. Mycologia 89: 199-219. 